\title{
Corrigendum to "Low-Level Laser Stimulation on Adipose-Tissue-Derived Stem Cell Treatments for Focal Cerebral Ischemia in Rats"
}

\author{
Chiung-Chyi Shen, ${ }^{1,2,3,4}$ Yi-Chin Yang, ${ }^{1}$ Ming-Tsang Chiao, ${ }^{1}$ \\ Shiuh-Chuan Chan, ${ }^{5}$ and Bai-Shuan Liu ${ }^{6}$ \\ ${ }^{1}$ Department of Neurosurgery, Taichung Veterans General Hospital, Taichung 40705, Taiwan \\ ${ }^{2}$ Department of Physical Therapy, Hung Kuang University, Taichung 43302, Taiwan \\ ${ }^{3}$ Department of Medicine, National Defense Medical Center, Taipei 114, Taiwan \\ ${ }^{4}$ Tri-Service General Hospital, National Defense Medical Center, Taipei 114, Taiwan \\ ${ }^{5}$ Graduate Institute of Pharmaceutical Science and Technology, Central Taiwan University of Science and Technology, \\ Taichung 40601, Taiwan \\ ${ }^{6}$ Department of Medical Imaging and Radiological Sciences, Central Taiwan University of Science and Technology, \\ Taichung 40601, Taiwan
}

Correspondence should be addressed to Bai-Shuan Liu; bsliu@ctust.edu.tw

Received 29 November 2015; Accepted 10 December 2015

Copyright (C) 2015 Chiung-Chyi Shen et al. This is an open access article distributed under the Creative Commons Attribution License, which permits unrestricted use, distribution, and reproduction in any medium, provided the original work is properly cited.

We have a clarification to make in our paper "Low-Level Laser Stimulation on Adipose-Tissue-Derived Stem Cell Treatments for Focal Cerebral Ischemia in Rats" [1]. Because the GAPDH gene is often stably and constitutively expressed at high levels in most cells and tissues, it is considered a housekeeping gene. For this reason, GAPDH is commonly used by biological researchers as a loading control for western blot. GAPDH was just used as internal control for gene expression analysis as it was supposed to have a uniform expression in both Figures 5(a) and 9(a).

\section{References}

[1] C.-C. Shen, Y.-C. Yang, M.-T. Chiao, S.-C. Chan, and B.-S. Liu, "Low-level laser stimulation on adipose-tissue-derived stem cell treatments for focal cerebral ischemia in rats," Evidence-Based Complementary and Alternative Medicine, vol. 2013, Article ID 594906, 12 pages, 2013. 


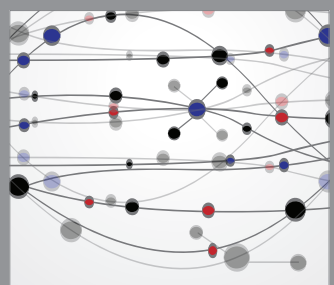

The Scientific World Journal
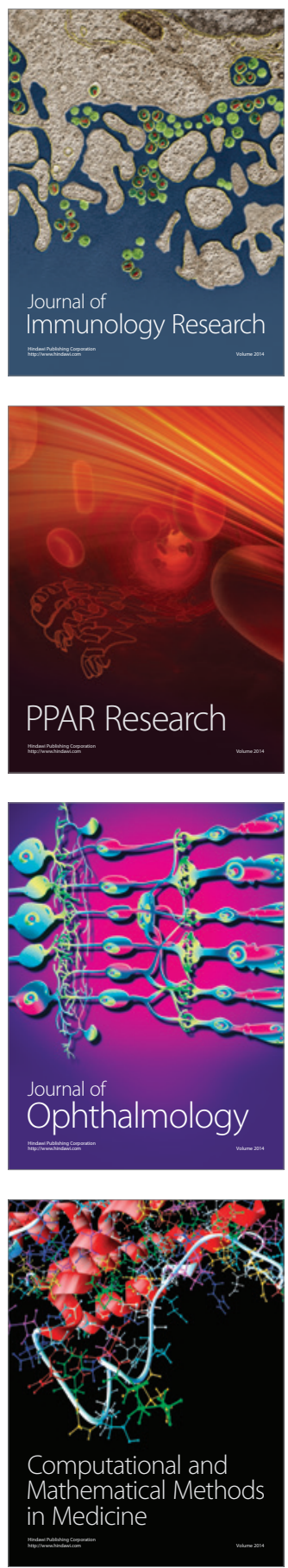

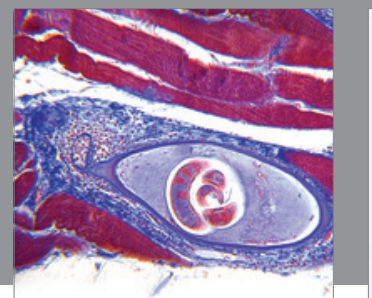

Gastroenterology

Research and Practice
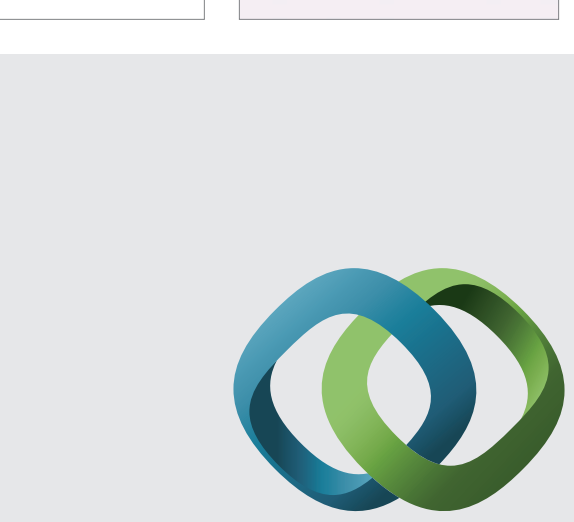

\section{Hindawi}

Submit your manuscripts at

http://www.hindawi.com
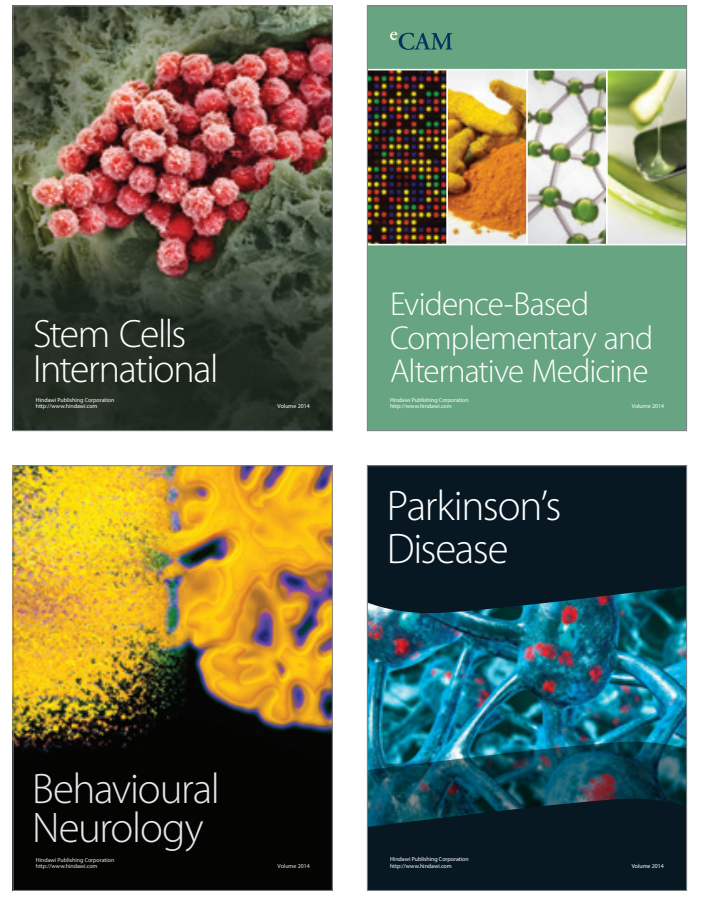
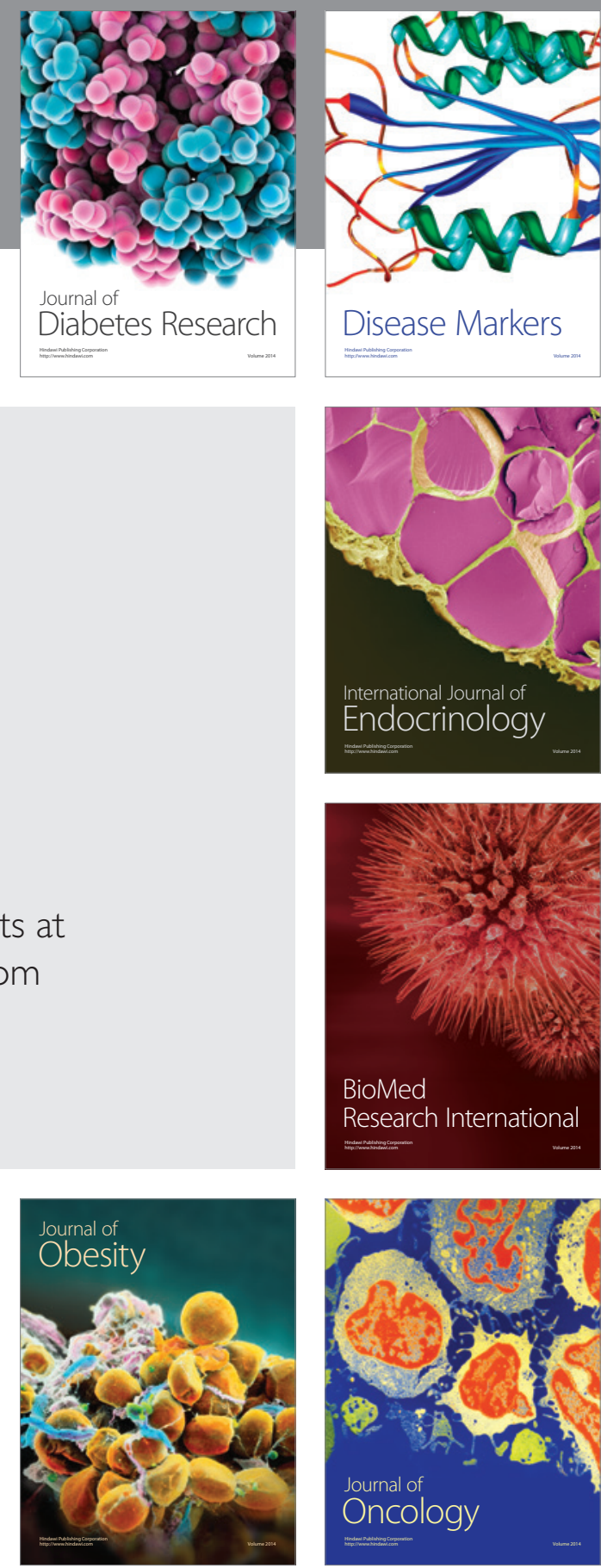

Disease Markers
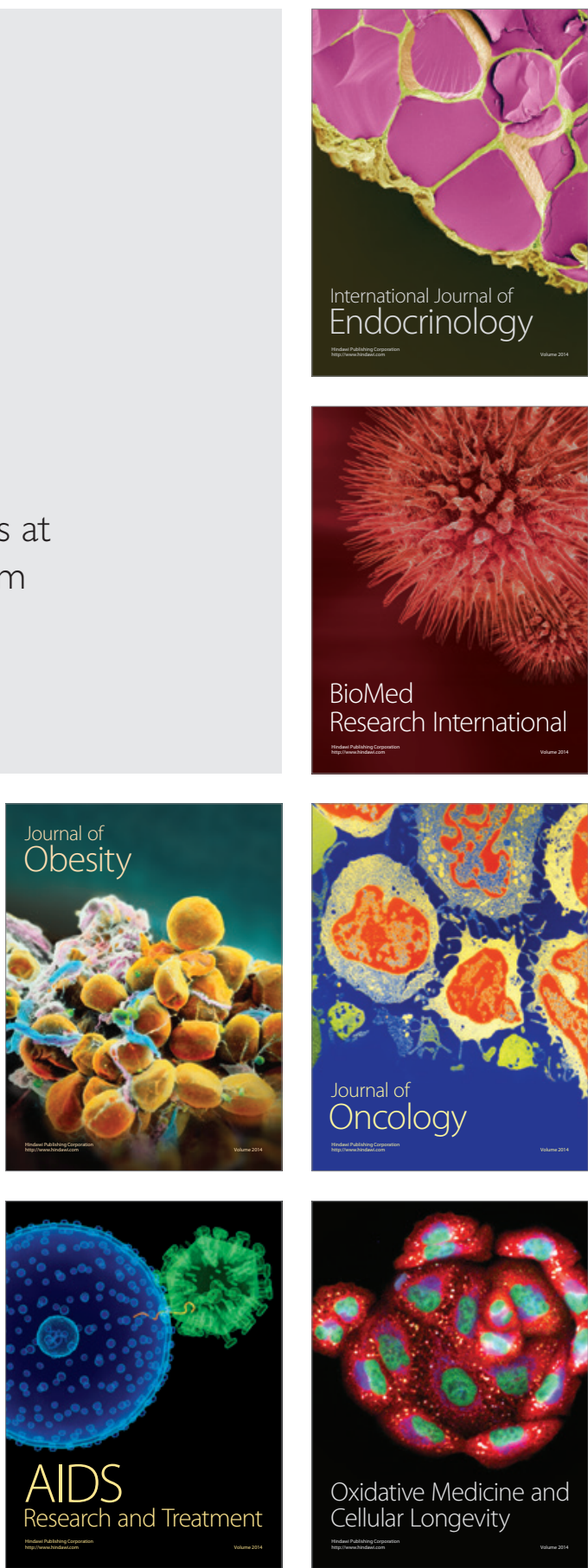